Jurnal Pendidikan dan Kebudayaan, No. 075, Tahun Ke-14, November 2008

\title{
Hubungan Minat Terhadap Profesi Guru dan Motivasi Berprestasi dengan Keterampilan Mengajar
}

\author{
H. Sholeh Hidayat \\ Ketua Lembaga Penelitian dan Pengabdian Kepada Masyarakat Universi- \\ tas Sultan Ageng Tirtayasa, email: shol_hidayat@yahoo.com
}

\begin{abstract}
Abstrak: Penelitian ini bertujuan untuk mengetahui seberapa kuat hubungan minat terhadap profesi guru dan motivasi berprestasi dengan keterampilan mengajar. Hasil Penelitian menunjukkan I) Minat terhadap profesi guru mahasiswa semester VIIJ jurusan Pendidikan matematika termasuk kategori tinggi, 2) Motivasi berprestasi mahasiswa semester VIII jurusan Pendidikan Matemtika termasuk kategori tinggi, 3) Keterampilan mengajar mahasiswa semester VII jurusan Pendidikan Matematika termasuk baik, 4) Minat terhadap profesi guru memiliki hubungan positif dengan keterampilan mengajar, 5) Motivasi berprestasi memiliki hubungan yang positif dengan keterampilan mengajar dan 6) Minat terhadap pofesi guru dan Motiovasi berprestasi secara bersama-sama memiliki hubungan positif dengan keterampilan mengajar. Untuk meningkatkan minat terhadap profesi guru dan motivasi berprestasi serta keterampilan mengajar para mahasiswa dalam pembelajaran PPL dan llmu Pembelajaran lainnya perlu diberikan pengalaman mengajar yang bermakna melalui pilihan strategi pembelajaran dan pemilihan media pembelajaran yang tepat.
\end{abstract}

Kata kunci: minat terhadap profesi guru, motivasi berprestasi, dan keterampilan mengajar 


\section{Pendahuluan}

Masalah yang menjadi sorotan utama pada Lembaga Pendidikan Tenaga Kependidikan (LPTK) adalah bagaimana LPTK dapat menghasilkan lulusan yang benar-benar memiliki kompetensi pedagogik, profesional, kepribadian dan sosial. Tenaga kependidikan guru merupakan suatu komponen penting dalam penyelenggaraan pendidikan yang bertugas menyelenggarakan kegiatan pembelajaran, melatih, meneliti, mengembangkan, mengelola dan memberikan layanan teknis dalam bidang pendidikan. Salah tugas utama guru sebagai pendidik profesional adalah mengajar disamping mendidik, membimbing, mengarahkan, melatih dan mengevaluasi peserta didik.

FKIP Universitas Sutan Ageng Tirtayasa sebagai LPTK bertujuan menyiapkan peserta didik menjadi tenaga pendidik profesional yang menguasai pengetahuan dan keterampilan menyelenggarakan pembelajaran. Sebelum mahasiswa melaksanakan kegaiatan praktik pengalaman lapangan (PPL) terlebih dahulu para mahasiswa diberikan seperangkat pengetahuan tentang bagaimana merencanakan, melaksanakan program dan proses pembelajaran pada mata kuliah Praktik Pengalaman Lapangan I (PPL 1).
Keterampilan mahasiswa dalam mengelola pembelajaran merupakan hasil dari berbagai faktor yang mempengaruhinya baik yang berasal dari dalam diri mahasiswa itu sendiri maupun dari luar. Secara sederhana dapat dikatakan, bahwa tingginya keterampilan mengajar dapat tergambar dari kualitas dan kemampuan lulusan LPTK dari suatu sitem pembelajaran yang dialaminya.

Kualitas lulusan suatu sistem pendidikan dipengaruhi oleh faktor kualitas masukan dan proses. Kualitas masukan antara lain mutu kemampuan mahasiswa, kurikulum, sarana dan prasaran pembelajaran, mutu manajemen dan ketersediaan anggaran yang memadai, kualitas proses mencakup mutu interaksi antara berbagai masuk yang dialami langsung oleh mahasiswa dalam kegiatan pendidikan dan pembelajaran Keterampilan mahasiswa dalam mengajar sebagai hasil dari proses pendidikan dan pembelajaran merupakan kemampuan yang dimiliki mahasiswa selama mereka mengikuti perkuliahan. Faktor-faktor yang turut mempengaruhi terhadap keterampilan mengajar tersebut meliputi faktor kurikulum, dosen pembimbing, guru pamong, proses pembelajaran dan karakteristik mahasiswa itu sendiri. Faktor kurikulum meliputi sistem dan 
strategi pembelajaran, sistem administrasi dan sistem evaluasi. Faktor dosen pembimbing, guru pamong dan sumber belajar lainnya tergantung pada latar belakang kognitif dan afektifnya sedangkan proses pembelajaran dipengaruhi oleh kualitas proses pembelajaran, kualitas interaksi antara dosen pembimbing dan guru pamong dengan mahasiswa dan faktor sumber belajara lainnya serta faktor yang berhubungan dengan karakteristik mahasiswa seperti kecerdasan intelektual, motivasi, minat, sikap, konsep diri dan kecakapan nyata yang tercermin dari prestasi belajar yang telah dimilikinya.

Oleh karena faktor internal dan eksternal yang berbeda-beda dari setiap mahasiswa, maka dengan sendirinya timbul perbedaan antara mahasiswa yang satu dengan yang lainnya. Dengan adanya perbedaan ini, maka kecakapan dan keterampilan tiap mahasiswa pun berbeda pula. Dengan adanya perbedaan perbedaan baik kemampuan maupun keterampilan yang berhubungan dengan ranah kognitif, afektif dan psikomotor akan mempengaruhi keterampilan melaksanakan praktik pembelajaran mahasiswa Pendidikan Matematika FKIP di SMA. Apakah tingkat intelegensi mahasiswa berpengaruhi terhadap keterampilan mengajar? Apakah kemampuan awal mahasiswa mempengaruhi keterampilan mengajar? Apakah minat terhadap profesi guru mempengaruhi keterampilan mengajar? Apakah motivasi berprestasi mahasiswa berpengaruhi terhadap keterampilan mengajar? Apakah kemampuan dosen pembimbing dan guru pamong mempengaruhi terhadap keterampilan mengajar? Apakah konsep diri mahasiswa mempengaruhi terhadap keterampilan mengajar? Apakah sikap terhadap profesi guru mempengaruhi terhadap keterampilan mengajar ? Berdasarkan identifikasi masalah tersebut di atas banyak faktor yang diduga mempengaruhi keterampilan mengajar mahasiswa Pendidikan Matematika FKIP, dalam penelitian ini akan dibatasi pada masalah minat terhadap profesi guru dan motivasi berprestasi hubungannya dengan keterampilan mengajar atau kinerja guru dalam pembelajaran. Yang dimaksud dengan minat terhadap profesi guru adalah kecenderungan perhatian dan perasaan tertarik untuk melaksanakan upaya menjadi guru seperti kegiatan menambah pengetahuan yang berkaitan dengan keguruan, mengenal peserta didik dan meningkatkan keterampilan untuk menjadi guru, sedangkan 
motivasi berprestasi adalah dorongan yang sangat kuat untuk berusaha dan bekerja keras demi mencapai suatu keberhasilan dan keunggulan serta berusaha menghindari kegagalan.

Berdasarkan pembatasan masalah tersebut diajukan rumusan masalah sebagai berikut 1) Bagaimana minat mahasiswa terhadap profesi guru, 2) Bagaimana motivasi berprestasi mahasiswa semester VIII Jurusan Pendidikan Matematika FKIP Universitas Sultan Ageng Tirtayasa? Apakah terdapat hubungan minat terhadap profesi guru dan motivasi berprestasi baik sendiri-sendiri maupun secara bersama-sama dengan keterampilan mengajar mahasiswa Semester VIII Jurusan Pendjdikan Matematika FKIP Universitas Sultan Ageng Tirtayasa?

Secara operasional penelitian ini dilaksanakan dengan tujuan untuk memperoleh gambaran dan untuk mengetahui seberapa kuat 1) Minat terhadap profesi guru mahasiswa semester VIII Jurusan Pendidikan Matematika FKIP Untirta peserta PPL,

2) Motivasi berprestasi mahasiswa semester VIII Jurusan Pendidikan Matematika FKIP Untirta peserta PPL, 3) Hubungan antara minat terhadap profesi guru dengan keterampilan mengajar mahasiswa peserta PPL, 4) Hubungan antara motivasi ber- prestasi dengan keterampilan mengajar mahasiswa peserta PPL, dan 5) Hubungan antara minat terhadap profesi guru dan motivasi berprestasi secara bersama-sama dengan keterampilan mengajar mahasiswa peserta PPL.

\section{Kajian Literatur}

\section{Hakikat Keterampilan Mengajar}

Pembelajaran merupakan suatu poroses yang kompleks dan melibatkan berbagai aspek yang saling berkaitan. Oleh karena itu untuk mewujudkan pembelajaran yang efektif diperlukan berbagai keterampilan yaitu keterampilan mengajar. Keterampilan mengajar merupakan kompetensi pedagogik yang cukup kompleks karena ia merupakan integrasi dari berbagai kompetensi guru secara utuh dan menyeluruh. Turney (1973) dalam Irawan, Suciati dan Wardani (1994) mengemukakan terdapat delapan keterampilan mengajar yang sangat berperan dan menentukan kualitas pembelajaran yaitu keterampilan bertanya, memberi penguatan, mengadakan variasi, menjelaskan, membuka dan menutup pelajaran, membimbing diskusi kelompok kecil, mengelola kelas serta membelajarkan kelompok kecil dan perorangan. 
Direktorat Jenderal Dikdasmen (2004) menyatakan kompetensi pengelolaan pembelajaran meliputi kemampuan menyusun rencana pembelajaran, mengajar, menilai prestasi belajar dan melaksanakan tindak lanjut hasil penilaian prestasi belajar peserta didik. Kemampuan mengajar mencakup indikator-indikator sebagai berikut: membuka pelajaran dengan metode yang sesuai, menyajikan materi pelajaran secara sistematis, menerapkan metode dan prosedur pembelajaran yang telah ditentukan, mengatur kegiatan siswa di kelas, menggunakan media pembelajaran/peralatan praktikum dan bahan yang telah ditentukan, menggunakan sumber belajar yang terpilih, memotivasi siswa dengan berbagai cara yang positif, melakukan interaksi dengan siswa menggunakan bahasa yang komunikatif, memberikan pertanyaan dan umpan balik untuk mengetahui dan memperkuat penerimaan siswa dalam proses pembelajaran, menyimpulkan pembelajaran dan menggunakan waktu secara efektif dan efisien.

\section{Hakikat Motivasi Berprestasi}

Motivasi merupakan proses psikologis yang mencerminkan interaksi antara sikap, kebutuhan, persepsi yang terjadi pada diri seseorang.
Motivasi timbul diakibatkan oleh faktor di dalam diri seseorang yang disebut intrinsik dan faktror dari luar atau ekstrinsik (Wahyosamidjo,1987). Motivasi berprestasi menurut Hilgard (1983) adalah motif sosial untuk mengerjakan seuatu yang berharga atau penting dengan baik dan sempurna untuk memenuhi standar keunggulan dari apa yang dilakukan seseorang. Apa yang dilakukan seseorang pada dasarnya adalah untuk memperoleh pengakuan dari orang lain terhadap prestasi yang telab dicapainya terlebih lagi apabila prestasi tersebut dapat melebihi teman-temannya. McClelland (1975) menggunakan istilah need for achievement ( $n$ Ach) untuk kebutuhan berprestasi yaitu sebagai suatu dorongan pada seseorang untuk berhasil dalam berkompetisi dengan suatu standar keunggulan (standar of excellence). Seseorang yang memiliki motivasi berprestasi akan mencari situasi dimana mereka dapat mencapai tanggung jawab pribadi untuk menemukan pemecahan masalah dan merupakan tantangan untuk menyelesaikan problem serta menerima umpan balik sebagai tanggung jawab untuk sukses atau gagal, bukannya mengandalkan hasil pada kedaan tertentu ataupun kebutuhan dan mereka ingin merasa 
'sukses karena hasil mereka sendiri. Menurut Atkinson (1964) ada dua aspek yang mendasari motivasi berprestasi yaitu penghargaan untuk sukses dan menghindari kegagalan. Sedangkan menurut Jackson (1973) bahwa motivasi berprestasi merupakan dorongan yang sangat kuat untuk berusaha dan bekerja keras demi mencapai suatu keberhasilan dan keunggulan.

Beberapa ciri seseorang yang memiliki motivasi berprestasi tinggi antara lain adalah 1) memiliki tanggung jawab yang tinggi, 2) memiliki program kerja berdasarkan rencana dan tujuan yang realistik serta berjuang untuk mewujudkannya, 3) memiliki kemampuan untuk mengambil keputusan dan berani mengambil resiko, 4) melakukan pekerjaan yang berarti dan menyelesaikannya dengan hasil memuaskan dan 5) mempunyai kemampuan menjadi terkemuka yang menguasai bidang tertentu.Freud Luthans sebagaimana dikutip Miftah Toha (1990) mengemukakan karakteristik dari orang-orang yang berprestasi tinggi antara lain 1) suka mengambil resiko yang moderat, 2) memerlukan umpan balik yang segera, 3) memperhitungkan keberhasilan dan 4) menyatu dengan tugas. Sementara itu Gibson, Ivencevich dan Donelly
(1993) mengatakan bahwa orang yang memiliki motivasi berprestasi tinggi mempunyai harapan besar untuk sukses, melakukan usaha keras untuk mencapai tujuan dan tidak memikirkan akan adanya kegagalan.

\section{Hakikat Minat Terhadap Profesi Guru}

Menurut Sukardi (1994) minat adalah suatu perangkat mental yang terdiri dari kombinasi perpaduan dan campuran dari perasaan, harapan, prasangka, cemas, takut dan kecenderungan-kecenderungan lain yang bisa mengarahkan individu kepada suatu pilihan tertentu. Beller (1971) minat dapat diekspresikan melalui suatu pernyataan yang menunjukkan bahwa lebih menyukai sesuatu hal daripada hal lainnya, dapat pula dimanifestasikan melalui partisipasi dalam bentuk suatu aktivitas. Sedang menurut Aiken (1983) pada umumnya minat sebagai salah satu aspek tingkah laku afektif memiliki ciri-ciri antara lain bersosialisasi dengan aktivitas, bersifat tetap dan terus menerus, mempunyai intensitas dan kecenderungannya untuk menerima atau menolak untuk melakukan suatu aktivitas. Profesi menurut Sutjipto (2003) diartikan sebagai suatu pekerjaan yang bersifat relatif lama dan perlu pendidikan yang khusus 
serta perlu adanya latihan khusus pula. Menurut Dedi Supriadi (1998) profesi menunjukkan pada suatu pekerjaan atau jabatan yang menuntu keahlian, tanggung jawab dan kesetiaan terhadap pekerjaan itu. Sedangkan menurut Sahertian (1994) profesi adalah suatu pernyataan atau janji yang terbuka yang menyatakan bahwa seseorang itu mengabdikan dirinya pada suatu profesi atau pelayanan karena orang tersebut merasa terpanggil untuk menjabat pekerjaan itu. Adapun yang dimaksud dengan guru adalah pendidik profesional dengan tugas utama mendidik, mengajar, membimbing, mengarahkan, melatih, menilai dan mengevaluasi peserta didik pada pendidikan usia dini jalur formal, pendidikan dasar dan pendidikan menengah (UU. No.14/2005, Pasal 1). Adapun yang dimaksud dengan minat terhadap profesi guru adalah kecenderungan perhatian untuk melakukan upaya menjadi guru meliputi kegiatan menambah pengetahuan yang berkaitan dengan keguruan, mengenal peserta didik dan meningkatkan keterampilan untuk menjadi guru.

\section{Metodologi Penelitian}

\section{Metodologi, Tempat dan Waktu Penelitian}

Penelitian dilasanakan di SMA yang ada di Kabupaten Serang pada saat melaksanakan Praktik Pengalaman lapangan yang berlansgung mulai bulan Maret sampai dengan Juni 2006. Metode yang digunakan adalah metode survey dengan pendekatan korelasional. Variabel yang diteliti adalah keterampilan mengajar, (Y) minat terhadap profesi guru $\left(\mathrm{X}_{1}\right)$ dan Motivasi berprestasi $\left(\mathrm{X}_{2}\right)$.

\section{Populasi dan Sampel Penelitian}

Populasi sasaran adalah mahasiswa jurusan Pendikan Matematika FKIP Universitas Tirtayasa semester VIII yang sedang menjalankan Praktik Pengalaman Lapangan (PPL) dan yang menjadi sampel sebanyak sebanyak 35 orang yang diambil secara acak sederhana.

\section{Instrumen Penelitian}

Untuk memperoleh data variabel minat terhadap profesi guru dan motivasi berprestasi dijaring dengan menggunakan kuesioner model skala Likert dan data keterampilan mengajar menggunakan Instrumen Penilaian Kinerja Guru (IPKG) melalui pengamatan. 


\section{Hasil Penelitian dan Pembahasan}

\section{Hasil Penelitian}

Data hasil penelitian keterampilan mengajar diperoleh skor terendah 71 dan skor tertinggi 94 , skor rerata 86,29 , simpangan baku 5,94 , modus 84,50 dan median 85,73 . Sedangkan secara teoretik skor terendah 23 dan tertinggi 115 serta rerata teoretik 57,5. Dengan demikian Keterampilan mengajar mahasiswa termasuk kategori baik atau tinggi karena berada di atas rerata teoretik $(86,29>57,5)$.

Data minat terhadap profesi guru secara empirik menunjukkan skor terendah 18 dan skor tertinggi 29 , skor rerata 23,26 , simpangan baku 3,18 , modus 22,5 dan media 22,86 . Sedangkan secara teoretik skor terendah 1, tertinggi 36, dan rerata 18 . Dengan demikian minat terhadap profesi guru termasuk kategori tinggi $(23,26>18)$. Sedangkan data variabel motivasi berprestasi diperoleh skor terendah 103 dan skor tertinggi 124 , skor rerata 113,11 , simpangan baku 5,56 , modus 113,61 dan media 113,227.
Sedangkan secara teoretik skor terendah 33 dan tertinggi 165 serta rerata teoretik 82,5. Dengan demikian motivasi berprestasi mahasiswa semester VIII jurusan Pendidikan Matematika termasuk kategori tinggi $(113,11>82,5)$.

Berdasarkan pengujian hipotesis yang menyatakan bahwa terdapat hubungan minat terhadap profesi guru dengan keterampilan mengajar dapat dilihat pada Tabel 1.

Berdasarkan hasil perhitungan persamaan regresi minat terhadap profesi guru $\left(\mathrm{X}_{1}\right)$ terhadap keterampilan mengajar $(\mathrm{Y})$ diperoleh $\mathrm{Y}=$ $58,635+1,189 X 1$. Karena karena $F$ hitung $F_{\text {hitung }}>F_{\text {tabel }}(22,367>7,50)$ pada taraf signifikansi 0,01 maka koefisien regresi minat terhadap profesi guru adalah signifikan. Demikian pula dari hasil perhitungan linieritas diperoleh Fhitung $(2,188)<$ Ftabel $(2,30)$ maka garis persamaan regresi tersebut berbentuk linier. Selanjutnya dari hasil analisis korelasi diperoleh koefisien korelasi $r_{y \mid}=0,64$ yang

\section{Tabel 1 Uji Signifikansi koefisien korelasi Minat Terhadap Profesi Guru dengan Keterampilan Mengajar}

\begin{tabular}{|c|c|c|c|c|}
\hline $\mathrm{n}$ & $\mathrm{r}_{\mathrm{xy} 1}$ & $\mathrm{t}_{\text {hitung }}$ & \multicolumn{2}{|c|}{$\mathrm{t}_{\text {tabel }}$} \\
\hline & & & 0,05 & 0,01 \\
\hline 35 & 0,64 & 6,23 & 2,03 & 2,72 \\
\hline
\end{tabular}


signifikan pada taraf signifikansi 0,01 . Karena $t_{\text {hitung }}(6,23)>t_{\text {tabel }}(2,72)$, hal ini berarti Minat terhadap profesi guru $\left(X_{1}\right)$ memiliki hubungan dengan Keterampilan mengajar (Y), dengan kekuatan hubungan 0,62 . Karena koefisien determinasi yang diperoleh adalah sebesar 0,4096, maka 40,96\% variasi keterampilan mengajar $(\mathrm{Y})$ mahasiswa peserta PPL dapat dijelaskan oleh Minat terhadap profesi guru $\left(\mathrm{X}_{1}\right)$ melalui persamaan regresi $Y=58,635+1,189 \mathrm{X}_{1}$.

Hasil pengujian hipotesis kedua yang menyatakan bahwa terdapat hubungan motivasi berprestasi dengan keterampilan mengajar dapat dilihat pada Tabel 2.

Hasil perhitungan persamaan regresi motivasi berprestasi $\left(\mathrm{X}_{2}\right)$ terhadap keterampilan mengajar $(Y)$ diperoleh $Y=23,46+0,555 X_{2}$ Mengingat $F_{\text {hitung }}(11,761)>F_{\text {tabe }} 1(7,50)$, maka koefisien regresi motivasi berprestasi tersebut adalah signifikan. Demikian pula berdasarkan hasil perhitungan linieritas diperoleh $\mathrm{F}_{\text {hitung }}(0,878)<\mathrm{F}_{\text {tabe }} \mathrm{l}(3,19)$, maka garis persamaan regresi tersebut berbentuk linier. Selanjutnya karena hasil analisis korelasi diperoleh koefieien korelasi 0,52 yang signifikan pada taraf signifikansi 0,01 dan $t_{\text {hitung }}(4,09)$ $>t_{\text {tabel }}(2,72)$ maka motivasi berprestasi mempunyai hubungan positif dengan keterampilan mengajar dengan kekuatan hubungan 0,52. Koefisien determinasi yang di-peroleh sebesar $0,270 \%$, hal ini berarti bahwa $27,04 \%$ variasi keterampilan mengajar mahasiswa dapat dijelaskan oleh motivasi berprestasi melalui persamaan regresi $Y=23,46+0,555 X_{2}$.

Hasil pengujian hipotesis ketiga menyatakan terdapat hubungan antara Minat terhadap profesi guru $\left(\mathrm{X}_{1}\right)$ dan Motivasi Berprestasi $\left(\mathrm{X}_{2}\right)$ secara bersama-sama dengan $\mathrm{Ke}$ terampilan mengajar (Y). Hasil perhitungan persamaan regresi ganda minat terhadap profesi guru $\left(\mathrm{X}_{1}\right)$ dan motivasi berprestasi $\left(\mathrm{X}_{2}\right)$

\section{Tabel 2 Uji Signifikansi Koefisien Korelasi Motivasi Berprestasi dengan Keterampilan Mengajar}

\begin{tabular}{|c|c|c|c|c|}
\hline \multirow{2}{*}{$n$} & \multirow{2}{*}{$\mathrm{r}_{\mathrm{xy} 1}$} & \multirow{2}{*}{$t_{\text {hitung }}$} & \multicolumn{2}{|c|}{$\mathrm{t}_{\text {tabel }}$} \\
\cline { 4 - 5 } & & & 0,05 & 0,01 \\
\hline 35 & 0,64 & 6,23 & 2,03 & 2,72 \\
\hline
\end{tabular}


terhadap keterampilan mengajar (Y) diperoleh $Y=30,29+0,31 X 1+0,90 \times 2$. Mengingat $F_{\text {hitung }}\left(13,82>F_{\text {tabel }}(5,29)\right.$ maka koefisien regresi ganda signifikan. Hal ini berarti terdapat hubungan yang positif antara Minat terhadap Profesi guru $\left(X_{1}\right)$ dan Motivasi Berprestasi $\left(X_{2}\right)$ secara bersama-sama dengan keterampilan Mengajar (Y). Hasil uji signifikansi persamaan regresi ganda tersebut dapat dilihat pada Tabel 3 .

Selanjutnya dari hasil analisis korelasi ganda diperoleh koefisien korelasi $\mathrm{Ry}_{12} 0,68$ yang sangat signifikan pada taraf signifikansi 0,01 , karena $t_{\text {hitung }}(13,825)>t_{\text {tabel }}(5,29)$ hal ini berarti terdapat hubungan yang positif antara Minat terhadap profesi $\operatorname{guru}\left(\mathrm{X}_{1}\right)$ dan Motivasi Berprestasi $\left(X_{2}\right)$ secara bersama-sama dengan Keterampilan mengajar(Y). Kemudian diperoleh koefisien determinasi korelasi ganda sebesar 0,4624 yang berarti $46,24 \%$ variasi keterampilan mengajar mahasiswa peserta PPL(Y) sebagai variabel terikat dapat dijelaskan secara bersama-sama oleh minat terhadap profesi guru dan motivasi berprestasi melalui persamaan regresi $\mathrm{Y}=$ $30,29+0,31 X_{1}+0,90 X_{2}$

Berdasarkan hasil penelitian sebagaimana terlihat dalam pengujian hipotesis penelitian maka dapat dikemukakan pembahasan sebagai berikut.

Bertitik tolak dari hasil pengujian hubungan minat terhadap profesi guru dengan keterampilan mengajar menunjukkan bahwa terdapat hubungan yang berarti antara Minat terhadap profesi guru dengan Keterampilan mengajar. Mahasiswa yang mempunyai minat terhadap profesi guru yang tinggi terbukti memiliki keterampilan mengajar tinggi daripada mahasiswa

Tabel 3

Uji Signifikansi Regresi Ganda $\mathrm{Y}$ atas $\mathrm{X}_{1}$ dan $\mathrm{X}_{2}$ dengan persamaan $Y=30,29+0,31 X_{1}+0,90 X_{2}$

\begin{tabular}{|l|c|c|c|c|c|r|}
\hline \multirow{2}{*}{ Sumber Variansi } & \multirow{2}{*}{$\mathrm{dk}$} & $\mathrm{Jk}$ & \multirow{2}{*}{ RJK } & F Filung & \multicolumn{2}{c|}{ Ftabel } \\
\cline { 6 - 8 } & & & & & 0,05 & 0,01 \\
\hline Total direduksi & 34 & 1199,14 & & & & \\
\hline Regresi & 2 & 555,778 & 277,889 & 13,82 & 3,28 & 5,29 \\
\hline Sisa & 32 & 643,362 & 20,105 & & & \\
\hline
\end{tabular}


yang memiliki minat terhadap profesi guru yang rendah. Temuan ini sejalan dengan Sumantri (2007) bahwa mahasiswa calon guru (PGSD) yang memiliki kecenderungan minat tinggi terhadap profesi guru memiliki kemampuan yang tinggi dalam melaksanakan prosedur pembelajaran. Temuan ini pula sejalan dengan pandangan Rinehart (1983) sebagaimana dikutip Sumantri (2007) bahwa minat sangat besar pengaruhnya dalam mencapai prestasi dalam suatu pekerjaan, profesi atau karier, hal ini tidak dapat dipertanyakan lagi. Tidak akan mungkin orang yang tidak berminat akan suatu pekerjaan akan dapat menyelesaikan pekerjaan tersebut dengan baik. Jadi minat merupakan salah satu faktor yang berpengaruh terhadap arah pilihan profesi. Hal ini diperkuat juga oleh Clark dan Calvin Bovy (1981) yang menyatakan bahwa hasil belajar siswa di sekolah 79\% dipengaruhi oleh kemampuan dasar siswa dan $30 \%$ dipengaruhi oleh lingkungan.

Hasil pengujian hubungan motivasi berprestasi dengan keterampilan mengajar menunjukkan adanya hubungan yang berarti. Temuan ini sejalan dengan pendapat Toeti Soekamto ( 1993) dan Sardiman AM (1996) yang menyatakan bahwa motivasi merupakan faktor yang mempengaruhi proses dan hasil belajar. Tanpa adanya motivasi maka proses belajar mahasiswa tidak akan berjalan lancar dalam mencapai tujuan belajar. Mahasiswa yang mempunyai motivasi yang tinggi mempunyai harapan unstuk sukses. Motivasi pada diri mahasiswa dapat menimbulkan perubahan dan menentukan intensitas usaha belajar mahasiswa itu sendiri. Dengan adanya usaha yang tekun dan sungguh-sungguh yang didasari adanya motivasi, maka mahaiswa yang belajar itu akan dapat medahirkan prestasi yang baik. Intensitas motivasi seseorang akan menentukan tingkat pencapaian prestasi belajarnya. Dengan demikian motivasi berprestasi dapat berfungsi sebagai pendorong usaha dan pencapaian prestasi. Adanya hubungan yang signifikan antara motivasi berprestasi mahasiswa dengan keterampilan mengajar sebagai prestasi belajar pada tataran keterampilan adalah karena sesorang yang memiliki motivasi berprestasi mempunyai sifat-sifat antara lain 1) rasa percaya diri, 2) bertanggung jawab terhadap tugas, 3) mempunyai orientasi ke depan dan 4) menyukai tugas-tugas yang menantang (Davidoff:1987). Temuan yang dapat diambil dari penelitian ini adalah bahwa tinggi rendahnya keterampilan 
mengajar dalam rangka praktik pengalaman lapangan dipengaruhi oleh tinggi rendahnya motivasi berprestasi yang dimiliki setiap mahasiswa. Mahasiswa PPL akan memiliki keterampilan mengajar yang tinggi jika pada dirinya memiliki motivasi berprestasi yang tinggi pula. Sebaliknya mahasiswa yang motivasi berprestasinya rendah tidak akan memiliki keterampilan mengajar yang tinggi.

Hasil penelitian ini pula telah membuktikan bahwa minat terhadap profesi gurudan motivasi berprestasi secara bersama-sama memiliki hubungan yang positif dengan keterampilan mengajar mahasiswa peserta Praktik Pengalaman Lapangan di SMA. Dengan demikian dapat disimpulkan bahwa peningkatan minat terhadap profesi guru dan motivasi berprestasi secara bersamasama akan akan meningkatkan pula keterampilan mahasiswa dalam mengajar. Berkaitan dengan hasil penelitian ini dapat dikemukakan bahwa di dalam upaya meningkatkan keterampilan mengajar mahasiswa PPL, faktor minat terhadap profesi guru dan motivasi berprestasi mahasiswa disamping faktor-faktor lainnya perlu mendapat perhatian dari para desain sistem pembelajaran, penyusun bahan pembelajaran, pebelajar dan penyelenggara pendidikan bahkan mahasiswa itu sendiri. Sedangkan motivasi berprestasi mahasiswa dapat dipelihara dan ditingkatkan melalui berbagai aktivitas antara lain pemberian pengalaman kepada para mahasiswa untuk membangkitkan dorongan, memberikan kesempatan dan kemudahan untuk mencapai apa yang diinginkan dan memperoleh kepuasan. Beberapa jenis pengalaman yang dimaksud adalah pengalaman sukses, pengalaman untuk mengaktualisasikan diri, pengalaman melihat dan merasakan nilai manfaat yang diperoleh dari melaksanakan tugas-tugas yang diberikan dosen.

\section{Simpulan dan Saran}

\section{Simpulan}

Penelitian ini merupakan suatu survei yang dilakukan SMA yang berada di Kabupaten Serang untuk memperoleh gambaran mengenai hubungan minat terhadap profesi guru dan motivasi berprestasi dengan keterampilan mengajar. Berdasarkan hasil pengujian terhadap data yang diperoleh dalam penelitian ini, dapat disimpulkan sebagai berikut.

Mahasiswa peserta PPL Jurusan Pendidikan Matematika FKIP Universitas Sultan Ageng Tirtayasa 
peserta PPL di SMA Kabupaten Serang memiliki minat terhadap profesi guru, motivasi berprestasi dalam kategori yang tinggi dan keterampilan mengajar dalam kategori yang baik. Di samping itu terdapat hubungan yang positif antara a) minat terhadap profesi guru dengan keterampilan mengajar, b) motivasi berprestasi dengan keterampilan mengajar, dan c) minat terhadap profesi guru dan motivasi berprestasi secara bersama-sama dengan keterampilan mengajar.

\section{Saran}

Berdasarkan hasil analisis sebagaimana telah diuraikan di muka menunjukkan bahwa minat terhadap profesi guru dan motivasi berprestasi baik diteliti secara sendiri-sendiri maupun secara bersama-sama mempunyai hubungan yang signifikan dengan pencapaian keterampilan mengajar mahasiswa Pendidikan Matematika peserta PPL. Dari kenyataan tersebut maka di dalam upaya mengoptimalkan keterampilan mengajar perlu diikhtiarkan adanya peningkatan pengetahuan keterampilan dasar mengajar dan peningkatan motivasi berprestasi sebagai berikut.

Upaya meningkatkan minat terhadap profesi guru dan keterampilan dasar mengajar dengan cara menggunakan strategi pembelajaran yang dapat memberikan pengalaman yang bermakna bagi mahasiswa seperti strategi pembelajaran kooperatif dan kolaboratif, bermain peran dan simulasi dalam perkuliahan teori Praktik Pengalaman lapangan, melakukan pengkajian teori-teori dan prinsip profesi guru melalui diskusi dengan teman sejawat dan dosen pembimbing serta memberikan pengalaman belajar dengan membaca serta mendiskusikan buku-buku yang berisi tentang kisah sukses seorang gura dalam mengantarkan para siswanya serta anak-anaknya.

Upaya-upaya dosen mata Praktik Pengalaman Lapangan dan Ilmu Pembelajaran lainnya untuk mening-katkan motivasi berprestasi dapat dilakukan hal-hal sebagai berikut a) setiap bahan pelajaran yang dipelajari mahasiswa perlu dibuat menarik, proses pembelajaran dapat mengaktifkan mahasiswa belajar dengan mengajak para mahasiswa menemukan dan membuktikan yang sedapat mungkin memberikan kegunaan, b) mengorganisasi pengalaman belajar sedemikian rupa sehingga setiap mahasiswa pernah memperoleh kepuasan dan penghargaan, c) mengarahkan pengalaman belajar kepada keberhasilan, mempunyai orientasi kepada prestasi 
dan tingkat aspirasi yang hasil belajar yang telah dicapai realistik dengan memberikan tujuan- dengan memberikan tekanan kepada tujuan pembelajaran yang menantang hal-hal yang positif dan membiarkan tetapi memungkinkan dapat dicapai ma-hasiswa mengatur sendiri proses maha-siswa, memberiathukan hasil- belajarnya

\section{Daftar Pustaka}

Aiken, Lewis R. 1983. Psychological Testing and Assesment. Boston : Allyn and Bacon Inc.

Atkinson. 1964. Motivation in Fantasy, Action and Society. New Jersey : D. Van Narst and Company. Inc.

Beller \& Charles. 1971. The Psychology Of Human Growth And Development. New York : Holt Rineharta and Winston.

Davidof, Linda L. 1987. Instructional to Psychology. Toronto:McGraw-Hill Book Company

Ditjen Didkdasmen Depdiknas. 2004. Standar Kompetensi Guru Pendidikan Menengah.Jakarta: Ditjen Dikdasmen

Gibson JL, JM. Ivancevich dan JH. Donelly. 1993. Organisasi (Terj: Djarkasih). Jakarta: Erlanga

Hilgard, Ernest. 1983. Introduction to Psychology, New York: Harcoust B. Javanovic.

Irawan Prasetya, Suciati dan Wardani. 1994. Teori Belajar, Motivasi dan Keterampilan Mengajar. Jakarta : PAU, Ditjen Dikti, Depdikbud Jackson. 1973. Psychological Sit-Help. http://mentalhelp.net/psyhelp/chap 4/ htm. New York

McClelland. 1975. The Achievement Motive. New York: Irvington , 1961. The Achieving Society. Princeton : NJD. Van Nostrand Company.

Richard Clark, Calvin Bovy. 1981. Cognitive Prescriptive Theory and Psychoeducational Design, : California: University of Southern California.

Sahertian Piet A. 1994. Profil Pendidik Profesional. Yogyakarta: Andi Offset Sardiman AM. 1996. Interaksi dan Motivasi Belajar Mengajar. Jakarta : Grafindo Persada.

Sukardi, Dewa Ketut. 1994. Bimbingan Karir di Sekolah-Sekolah. Jakarta : 
Ghalia Indonesia

Soekamto Toeti.1993. Prinsip Belajar dan Pembelajaran. Jakarta:Ditjen Dikti Sumantri Mohamad Syarif. 2007. Pengaruh Umpan Balik dan Minat Profesi Guru Terhadap Kemampuan Melaksanakan Prosedur Pembelajaran Mahasiswa PGSD. (Disertasi PPS UNJ: tidak diterbitan)

Supriadi Dedi. 1998. Mengangkat Cita dan Martabat Guru. Yogyakarta : Adicita Karya Nusa.

Sutjipto dan Raflis Kosasi. 2003. Profesi Keguruan. Jakarta : Rineka Cipta Toha Miftah.1990. Perilaku Organisasi. Jakarta : Rajawali

Undang-Undang Nomor 14 Tahun 2005 tentang Guru dan Dosen, Semarang: Duta Nusindo

Wahyosamidjo. 1987. Kepemimpinan dan Motivasi. Jakarta: Graha Indonesia 